\title{
EVALUATION OF ANTIBACTERIAL ACTIVITY OF SILVER NANOPARTICLES AGAINST METHICILLIN-RESISTANT STAPHYLOCOCCUS AUREUS AND DETECTION OF VIRULENCE FACTORS - NUCLEASE, PHOSPHATASE, AND BIO FILM PRODUCTION
}

\author{
MANIPRIYA B, TASNEEM BANU*, PREM KUMAR L, KALYANI M \\ Department of Microbiology, Saveetha Medical College and Hospital, Thandalam, Kanchipuram, Tamil Nadu, India. \\ Email: dr.tasneemnawaz@gmail.com
}

Received: 04 December 2017, Revised and Accepted: 29 January 2018

\begin{abstract}
Objective: To determine the virulence factors-biofilm, nuclease and phosphatase production in Staphylococcus aureus isolates. To determine the effect of silver nano particles and antibiotics on MRSA by MIC determination and kirby baeur method respectively and finally to compare antibacterial activity of silver nano particles and antibiotics.
\end{abstract}

Methods: In the present study, we explore the antibacterial activity of silver nanoparticles (Ag-NPs) dispersion (10 nm) against reference strain and clinical isolates of methicillin-resistant Staphylococcus aureus (MRSA). We evaluated the antibacterial activity of Ag-NPs against MRSA isolated from patients in Saveetha Medical College and Hospital, a tertiary care centre in Chennai, Tamil Nadu. The bactericidal activity of different concentrations of Ag-NPs $(200,100,50,25,12.5,6.25,3.125$, and $1.5625 \mu \mathrm{g} / \mathrm{ml})$ was tested by determining MIC using microbroth dilution and MBC by agar dilution methods.. In addition, the virulence factors phosphatase, nuclease, and biofilm production were tested.

Result: The values of minimal inhibitory concentration and minimal bactericidal concentration of Ag-NPs against all clinical isolates of MRSA and a single of $S$. aureus were found in the range of $12.5-50 \mu \mathrm{g} / \mathrm{ml}$ and $12.5-25 \mu \mathrm{g} / \mathrm{ml}$, respectively, indicating very good bactericidal activity. Ag-NPs with the highest concentration showed almost no growth for up to $16 \mathrm{~h}$ representing a bactericidal effect at this concentration. Effect was proportional to dose since $50.0 \mu \mathrm{g} / \mathrm{ml}$ was the most effective dose since the bacterial population did not recover and $12.5 \mu \mathrm{g} / \mathrm{ml}$ was the least effective. All the MRSA isolates were positive for the virulence factors.

Conclusion: The study result suggests that Ag-NPs could be used as an effective alternative antibacterial agent.

Keywords: Nanoparticles, Silver nanoparticles, Methicillin-resistant Staphylococcus aureus, Biofilm, Nuclease, Phosphatase.

(c) 2018 The Authors. Published by Innovare Academic Sciences Pvt Ltd. This is an open access article under the CC BY license (http://creativecommons. org/licenses/by/4. 0/) DOI: http://dx.doi.org/10.22159/ajpcr.2018.v11i5.24097

\section{INTRODUCTION}

Methicillin-resistant Staphylococcus aureus (MRSA) is S. aureus resistant to all beta-lactam antibiotics. Infections caused by Staphylococcus aureus have a poorer prognosis when the infecting strain is an MRSA [1]. Professor Patricia Jevons first observed Staphylococcus aureus that was resistant to Methicillin in Guildford, Surrey. Genetic changes in the MRSA have led to the evolution of "fitter" strains that combine antibiotic resistance with transmissibility and virulence [2]. MRSA is the leading cause of potentially life-threatening bloodstream infections, surgical site infections, and pneumonia.

In the human body, the main site of colonization of $S$. aureus is the anterior nares. Evasion of host's immune system is the primary pathogenic mechanism for its transformation from a commensal to a pathogen. The postulated sequence of events which leads to infection is initiated with carriage of the organism. It is disseminated through hand carriage to body sites where infection may occur in areas with breaks in dermal surfaces such as intravascular catheterization, operative incisions or minor abrasions in eczema, or shaving associated microtrauma.

The main mechanism of methicillin resistance is mediated by PB2a, encoded by mecA gene. PBP 2a blocks binding of all beta-lactams but allows transpeptidation to proceed. MRSA contains a resistance island called SCCmec, where SCC stands for staphylococcal cassette chromosome and mec stand for the mecA gene. Although the origin of SCC mec remains unknown, the cassette could have originated from Staphylococcus sciuri, since a PBP was found in S. sciuri that showed 87.8\% amino acid sequence identity with PB2a [3]. The first strains of MRSA were reported in the United Kingdom in 1961.The first important outbreak in the United States was in 1968. The second wave of MRSA emerged in the 1970s and 1980s in Australia, Irish Republic, and United States. However, reports of the hospital and inter-hospital spreads were increasing [4]. Since 1990s in many countries, the prevalence of MRSA has increased dramatically [5].

Epidemiologically MRSA has been classified as hospital-acquired (HAMRSA) and community-acquired MRSA (CA-MRSA). HA-MRSA is an MRSA infection which occurs after $48 \mathrm{~h}$ of hospitalization. CA-MRSA is strains isolated in an outpatient setting, from patients within $48 \mathrm{~h}$ of admission with criteria which includes patients having no history of MRSA infection or colonization, no admission to a health-care facility in the previous year, no history of dialysis, surgery or permanent indwelling catheters or medical devices that pass through the skin.

In addition to antibiotic resistance, one of the virulence factors responsible for treatment failure and chronic and recurrent staphylococcal infections in burn patients is biofilm formation [6,7]. Since the ability of biofilm production by MRSA increases antibiotic resistance, hospital patients 
infected with these strains are at serious risk for treatment failure [8]. Biofilm formation is considered to be a virulence factor because the microorganisms that establish in a burn wound biofilm fundamentally differ from suspended populations [9]. The signals that promote biofilm rapid formation are (i) presence of a suitable surface; (ii) increase of extracellular iron; and (iii) presence of indole, polyamines, calcium, and bile salts [10-12]. In the initial phase of biofilm formation, bacterial attacks proliferate, forming microcolonies and attracting surrounding cells. The mature biofilm is a real microbial community that exchanges and shares products in a dynamic manner [13]. The pathogenicity of biofilms can be summarized by the following properties: (i) Attachment to solid surfaces to high density; (ii) increased metabolic efficiency of the community; (iii) evasion of host-defenses; (iv) horizontal gene transfer; (v) antimicrobial resistance; and (vi) detachment of microbial aggregates able to colonize other sites. Biofilm acts as a barrier to antimicrobial agents and the host immune system that assists sustained bacterial colonization [14]. Biofilm formation is regulated by expression of polysaccharide intracellular adhesin (PIA) which mediates cell to cell adhesion and is the gene product of intracellular adhesion (ica) ADBC [15]. Various reports attest to the presence of ica ADBC gene in $S$. aureus and Streptococcus epidermidis isolated from infections associated with indwelling medical devices [16,17]. It was found that the ica locus is required for biofilm production [16]. Other studies have revealed that all strains bearing the icaA gene, a component of the ica locus, also bear icaD [17]. Thus, detection of one of these genes can be used to determine whether $S$. aureus is a potential biofilm producer. Production of ica ADBC-encoded, $\mathrm{PIA}$ /poly-N-acetylglucosamine, represents an important biofilm mechanism in staphylococci. Glucose-induced biofilm in MRSA was ica independent and apparently mediated by a protein adhesion (s) [18]. Experiments have been performed which shows that $S$. aureus has become resistant to methicillin as it is covered by biofilms [46].

A heat-stable nuclease or thermonuclease is produced by most strains of $S$. aureus. Phosphatase is probably produced by all staphylococci. A large percentage (95-100\%) of the strains of S. aureus, Staphylococcus hyicus, Staphylococcus Intermedius, and Staphylococcus schleiferi produce detectable levels of thermonuclease [19]. The discovery of neutrophil extracellular traps (NETs) has opened a novel dimension in our understanding of how these specialized leukocytes kill pathogens. NETs consist of nuclear deoxyribonucleic acid (DNA) backbone associated with antimicrobial peptides, histones, and proteases that provide a matrix to entrap and kill various microbes. The study by Brenda et al. shows that $S$. aureus nuclease promotes resistance against NET-mediated antimicrobial activity of neutrophils and contributes to disease pathogenesis in vivo [20].

Phosphatase is probably produced by all Staphylococci. S. aureus, $S$. epidermidis, and Staphylococcus xylosus give positive results. The enzyme is repressed by inorganic phosphates in the medium in other species, so they give negative results by standard methods of testing [21].

In an era where antibiotics seem weakened and beginning to succumb to the battle against microbes, the field of nanobiotechnology holds a promising future. Nanotechnology offers opportunities to re-explore the biological properties of already known antimicrobial compounds by manipulating their size to alter their effect. Recent advances in the field of nanotechnology, particularly the ability to prepare highly ordered nanoparticulates of any size and shape, have led to the development of new biocidal agents [22]. In the study by Sunita and Palaniswamy showed The SN10 had shown the larger zone of inhibition as compared to SN5, from which it is concluded that smaller particle size gives better penetration and good antimicrobial activity [47].

The bactericidal effect of silver nanoparticles (Ag-NPs) is due to the following mechanism of actions. Ag-NPs attach to the surface of cell membrane, penetrate bacteria and release silver ions [23]. Binding to the bacterial membrane results in dissipation of the proton motive force [24].They target protein synthesis, nucleic acid synthesis and
Gram-positive cell wall synthesis [25]. Ag-NPs inactivate DNA replicating ability [26]. They disrupt cell permeability and respiratory functions of the cell. Smaller Ag-NPs having a larger surface area available for interaction have a greater bactericidal effect [27]. The antibacterial activity was particle size dependent. Small particles exhibited higher antimicrobial activity than big particles [28]. This result can be due to high particle penetration when these particles have smaller sizes [29]. Electrostatic forces that develop when nanoparticles with a positive zeta potential encounter bacteria with a negative surface charge promote a closer attraction and interaction between the two entities and possibly the penetration in bacterial membranes. Indeed, the zeta potential along with the size of the nanoparticles is a fundamental parameter for controlling the antimicrobial activity, and more effective nanoparticles have a positive zeta potential and a reduced size. Ag-NPs can not only alter the expression in effect; nanoparticles have a higher antibacterial activity than the free ions of silver, whereby the antibacterial properties are attributed to both the physical properties of nanoparticles and the elution of silver ions to produce a strong antibacterial activity of broad spectrum [30]. Furthermore, the fact that bacterial resistance to elemental silver is extremely rare [31] emphasizes the presence of multiple bactericidal mechanisms that act in synergy. The Ag-NPs also damage membranes and induce the release of reactive oxygen species, forming free radicals with a powerful bactericidal action [32]. Moreover, Ag-NPs are also responsible for cytokine modulation in wound healing [33] and inhibition of the biofilm formation.

In theory, a bactericidal agent is preferred clinically because bacterial killing should produce a faster resolution of infection, improve clinical outcome and reduce likelihood of emergence of resistance and spread of infection. If pathogens are killed rather than inhibited, resistance mutations that might otherwise emerge as the result of antibiotic pressure are eliminated [34].One of the principal elements of bacterial infectivity is their rapid reproduction time. As shown by the time-kill assays, Ag-NPs were effective in inhibiting bacterial growth in a dose and time-dependent manner [25]. The highest sensitive antimicrobial activity was observed against MRSA followed by methicillin-resistant S. epidermidis and Streptococcus pyogenes; while with Salmonella typhi and Klebsiella pneumoniae moderate antimicrobial activity were observed [26]. Among all nanoparticles, Ag-NPs have proved to be the most effective antimicrobial agent against bacteria, viruses, and other eukaryotic microorganisms [35].

In view of this background, the present study has been carried out to find out the efficacy of silver nanoparticles against MRSA. This was done by comparing the minimal inhibitory concentration (MIC) of AgNPs and efficacy of antibiotics against MRSA.

\section{MATERIALS AND METHODS}

Before beginning the study, clearance from Institutional Ethics Committee was obtained. This prospective study of 6 months duration was conducted at Saveetha Medical College a tertiary care hospital in Chennai, Tamil Nadu, South India.

\section{Sample size}

Among isolates of $S$. aureus from exudates, blood, respiratory, and urine specimens, 30 MRSA were collected. The isolates were confirmed as $S$. aureus by the tube coagulase test, mannitol fermentation test, and urease test.

\section{Confirmation of MRSA}

Confirmation of MRSA strains was done using the cefoxitin disc diffusion. Kirby-Bauer method was used in accordance with the Clinical Laboratory Standards Institute (CLSI) using ATCC S. aureus 25923 as a control. The medium used was Cation-adjusted Mueller-Hinton Agar. Inoculum was direct colony suspension equivalent to 0.5 McFarland standards. The media were incubated at $37^{\circ} \mathrm{C}$ at ambient air for 16-18 h. The strength of the cefoxitin disc was $30 \mu \mathrm{g}$. The isolates were considered methicillin-resistant if zone of inhibition [43]. 


\section{Biofilm assay}

Tissue culture plate method

This quantitative test described by Christensen et al. [36] is considered the gold-standard method for biofilm detection. 30 isolates from fresh agar plates were inoculated in $10 \mathrm{~mL}$ of trypticase soy broth with $1 \%$ glucose. Broths were incubated at $37^{\circ} \mathrm{C}$ for $24 \mathrm{~h}$. After $24 \mathrm{~h}$ incubation, the planktonic cells in MTPs were removed by rinsing the wells. The wells were rinsed twice with phosphate buffer saline $\mathrm{P}^{\mathrm{H}} 7.2$. The surfaceadhered cells in the MTP wells were stained with $250 \mu$ l of $0.2 \%$ crystal violet solution (HiMedia, India). The solution was left in MTP wells for $10 \mathrm{~min}$. Then, the excess crystal violet solution was removed. Hence, the crystal violet in stained cells was solubilized with $1 \mathrm{ml}$ of $95 \%$ ethanol. The biofilm biomass was quantified by measuring the intensity of crystal violet solution. The intensity was measured at an optical density (OD) $650 \mathrm{~nm}$ using ultraviolet-visible spectrophotometer [37,44]. OD of stained adherent biofilm was obtained using micro ELISA auto-reader (model 680, Biorad) at wavelength $650 \mathrm{~nm}$ (Table 1).

\section{Heat-stable nuclease (thermonuclease, DNase) test}

Toluidine blue DNA agar is used. Colonies producing DNase hydrolyzes the DNA content of toluidine blue DNA agar medium located in their immediate vicinity. This test was carried out using commercially available DNase agar (Sisco). Spot inoculation of the organism was done on the DNase agar and incubated at $37^{\circ} \mathrm{C}$ for $18-24 \mathrm{hrs}$. After incubation, $1 \mathrm{~N} \mathrm{HCl}$ was poured on the agar. Clearing around the bacterial growth was evaluated as positive [45].

\section{Phosphatase test}

Staphylococcal colonies are grown overnight at $37^{\circ} \mathrm{C}$ on phenolphthalein diphosphate agar. A few drops of ammonia solution are poured onto the lid and the plate is inverted. The colonies which turn bright pink within a few minutes are read as positive for phosphatase production.

\section{Materials}

Ag-NPs (product number from Sisco Research laboratories) of $10 \mathrm{~nm}$ particle size were used in this study. The stock concentration of $1 \mathrm{mg} / \mathrm{ml}$ solution was prepared freshly before using for MIC and MBC determination.

\section{MIC determination}

Initially, on MHA plates, bacterial strains were grown overnight at $35^{\circ} \mathrm{C}$. Further, using the standard broth dilution method (CLSI M07-A8), antimicrobial activity of Ag-NPs was examined. Accordingly, by the microdilution method in Luria-Bertani (LB) broth (Hi-Media) using serial two-fold dilutions of Ag-NPs in concentrations ranging from 200 to $1.5625 \mu \mathrm{g} / \mathrm{ml}$ with bacterial inoculums of $2 \times 108 \mathrm{CFU} / \mathrm{ml}$. They were incubated at a temperature of $37^{\circ} \mathrm{C}$ for $24 \mathrm{~h}$. MIC was determined.

\section{Minimal bactericidal concentration (MBC)}

Agar dilution method was used for estimation of MBC. Serial two-fold dilutions of Ag-NPs in saline were prepared in concentrations ranging from 200 to 1.625 , which were taken in test tubes and mixed with the MHA agar medium, and poured onto plates. The 30 MRSA strains were streaked by single streak method and were incubated for $24 \mathrm{~h}$

Table 1: MIC and MBC values of MRSA

\begin{tabular}{llll}
\hline MRSA (30) & & & \\
\hline $\begin{array}{l}\text { Number of } \\
\text { isolates }\end{array}$ & MIC $(\mu \mathrm{g} / \mathrm{ml})$ & $\begin{array}{l}\text { Number of } \\
\text { isolates }\end{array}$ & MBC $(\mu \mathrm{g} / \mathbf{m l})$ \\
\hline 16 & 12.5 & 17 & 12.5 \\
14 & 25 & 13 & 25 \\
\hline
\end{tabular}

MIC: Minimal inhibitory concentration, MBC: Minimal bactericida concentration, MRSA: Methicillin-resistant Staphylococcus aureus at $37^{\circ} \mathrm{C}$. The $\mathrm{MBC}$ endpoint is defined as the lowest concentration of antimicrobial agent that kills $100 \%$ of the initial bacterial population. After $24 \mathrm{~h}$, the MBC was noted down for each of the strains.

\section{Antibiotic susceptibility testing}

This was done by Kirby-Bauer method according to CLSI guidelines 2017. The antibiotics, which were tested, were Gentamicin $10 \mu \mathrm{g}$, Eythromycin $15 \mu \mathrm{g}$, Clindamycin $2 \mu \mathrm{g}$, Ciprofloxacin $5 \mu \mathrm{g}$, and Linezolid $30 \mu \mathrm{g}$.

\section{RESULTS AND DISCUSSION}

\section{Sample size}

Out of 45 samples confirmed as $S$. aureus by tube coagulase test, mannitol fermentation and urease tests, 30 were determined as MRSA by the cefoxitin disc diffusion method. The strains were numbered from 1 to 30 .

The 30 MRSA isolates were subjected to biofilm, nuclease, and phosphatase detection.

\section{Biofilm assay}

\section{Tissue culture plate method}

OD of stained adherent biofilm was obtained using micro ELISA autoreader (model 680, Biorad) at wavelength $650 \mathrm{~nm}$. The classification of bacterial adherence was done by TCP method [38].

\begin{tabular}{lll}
\hline Mean OD values & Adherence & Biofilm formation \\
\hline$<0.12$ & Non & Non/weak \\
$0.120-0.240$ & Moderately & Moderate \\
$>0.240$ & Strong & High \\
\hline
\end{tabular}

OD: Optical density

The results of biofilm TCP method are tabulated in Table 2 and Fig. 1.

Nearly $50 \%$ of the MRSA isolates are strong producers of biofilm, 33.3\% are moderate producers, and $16.7 \%$ are weakest producers. Our study results differ from that of Mathur et al., where they have used $152 \mathrm{~S}$. aureus isolates. They have compared different media such as TSB with $1 \%$ glucose and BHI. They have obtained the best results with TSB with $1 \%$ glucose. Out of the 152 isolates, $22(14.5 \%)$ were strong producers of biofilm, $52(34.2 \%)$ were moderate producers, and $70(46 \%)$ were weak producers. The study of Grinholc et al. showed that $45 \%$ of MRSA were producers of biofilm which is comparable to our study [39].

\section{Nuclease test}

This was done on Toluidine blue DNA agar. Out of 30 MRSA isolates, 28 were positive for thermonuclease production. The strains number 13 and 20 did not produce thermonuclease. A positive zone of nuclease production was figured out in Fig. 2.

\section{Test for phosphatase production}

This test was done on phenolphthalein diphosphate agar. Out of the 30 MRSA isolates, 29 of them produced phosphatase (Fig. 3). Isolate number 5 did not produce phosphatase.

\section{RESULTS AND DISCUSSION FOR MIC AND MBC}

The bactericidal activity of Ag-NPs of concentrations (200, 100, 50, $25,12.5,6.25,3.125$, and $1.5625 \mu \mathrm{g} / \mathrm{ml}$ ) were tested and are shown in Fig. 4. A very low (i.e., in the range of $12.5-50 \mu \mathrm{g} / \mathrm{ml}$ ) MIC and MBC values of Ag-NPs against MRSA strains recovered from patients from our tertiary care hospital were observed, indicating very good bacteriostatic and bactericidal activity of Ag-NPs (Table 1). Ag-NPs MIC and MBC value of reference strain $S$. areas ATCC 25923 was found to be very low, i.e., $12.5 \mu \mathrm{g} / \mathrm{ml}$ and $25 \mu \mathrm{g} / \mathrm{ml}$, respectively, study, MIC and MBC of Ag-NPs against MRSA were estimated to $50 \mu \mathrm{L}$. The values of 
Table 2: Biofilm assay

\begin{tabular}{|c|c|c|c|}
\hline Number of MRSA & Strong $(>0.240 \pm 0.022)$ & Moderate $(0.120-0.240 \pm 0.020)$ & Weak $(0.120 \pm 0.012)$ \\
\hline 30 & 15 & 10 & 5 \\
\hline
\end{tabular}

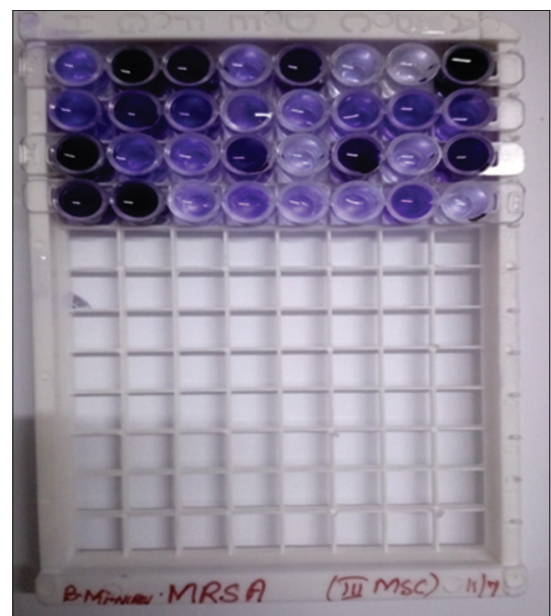

Fig. 1: Screening of biofilm producers by TCP method: High, moderate, and non slime producers differentiated with crystal violet staining in 96 well tissue culture plate



Fig. 2: Clearing produced by nuclease production in positive strain

MIC and MBC of Ag-NPs against all clinical isolates of MRSA and a single strain of S. aureus ATCC25923 were found in the range of 12.5-50 $\mu \mathrm{g} /$ $\mathrm{ml}$ and $12.5-25 \mu \mathrm{g} / \mathrm{ml}$, respectively. Figs. 4 and 5 show MIC and MBC results.

\section{MIC and MBC of ATCC S. aureus 25923 were 12.5 and $25(\mu \mathrm{g} / \mathrm{ml})$.}

Our study was comparable with that of Rangari et al., they also had a similar MIC and MBC values for MRSA. In their study, Ansari et al. stated the values of MIC and MBC of Ag-NPs against all clinical isolates of MSSA, MRSA, and a single strain of $S$. aureus ATCC25923 were found in the range of $12.5-50 \mu \mathrm{g} / \mathrm{ml}$ and $12.5-100 \mu \mathrm{g} / \mathrm{ml}$, respectively [40]. Their value of MBC is high compared to our study. The study by Li et al. concentrated on the antibacterial activity and mechanism of Ag-NPs (Ag-NPs) on S. aureus ATCC 6538P. The experiment results showed the MBC of Ag-NPs to $S$. aureus was $20 \mu \mathrm{g} / \mathrm{ml}$. At a concentration of $50 \mu \mathrm{g} / \mathrm{ml}$ for $12 \mathrm{~h}$, Ag-NPs reduce the enzymatic activity of respiratory chain dehydrogenase. Furthermore, the proteomic analysis showed that

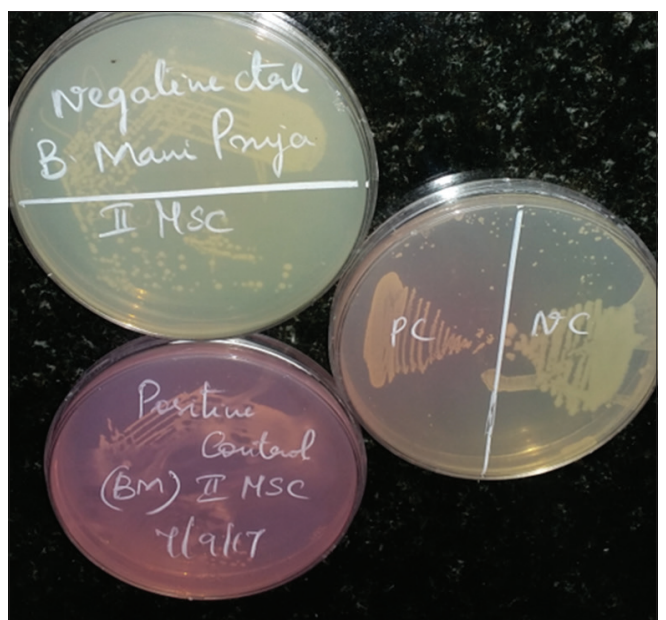

Fig. 3: Pink colour produced by phosphatase positive strains

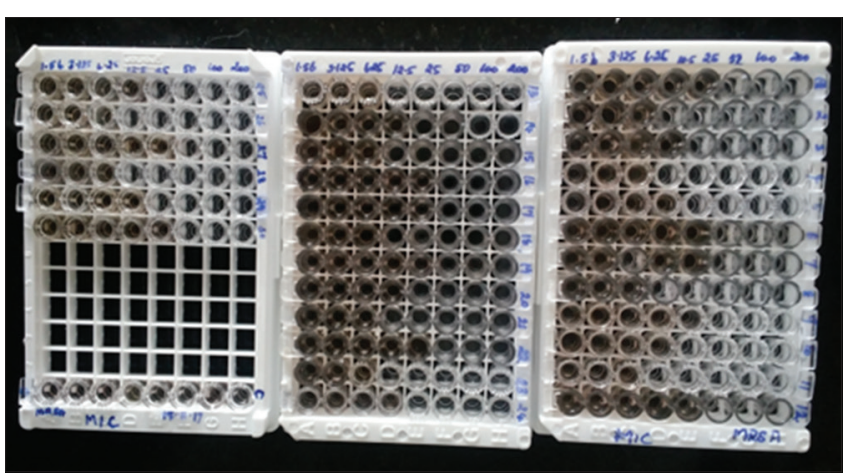

Fig. 4: Minimal inhibitory concentration determination

the expression abundance of some proteins was changed in the treated bacterial cell with Ag-NPs, formate acetyltransferase increased 5.3-fold in expression abundance, aerobic glycerol-3-phosphate dehydrogenase decreased 6.5-fold, ABC transporter ATP-binding protein decreased 6.2fold, and recombinase A protein decreased 4.9-fold [41]. The study by Kim et al. revealed MIC of AgNPs against S. aureus was $100 \mu \mathrm{g} / \mathrm{ml}$ [42].

Comparison of antibacterial activity of Ag-NPs and antibiotics The antibiotics tested were gentamicin $10 \mu \mathrm{g}$, erythromycin $15 \mu \mathrm{g}$, clindamycin $2 \mu \mathrm{g}$, ciprofloxacin $5 \mu \mathrm{g}$, and linezolid $30 \mu \mathrm{g}$.

Antibiotic susceptibility testing was done by Kirby-Bauer method according to CLSI guidelines 2017 for the 30 MRSA isolates.

All the isolates were susceptible to gentamicin. $70 \%$ of the isolates were susceptible to clindamycin. None of the isolates were susceptible to erythromycin, $90 \%$ of the isolates tested intermediate, and $10 \%$ of the isolates were resistant. $70 \%$ of the isolates were susceptible to ciprofloxacin. Moreover, all of the 30 isolates were susceptible to linezolid.

The antimicrobial activity of the $10 \mathrm{~nm}$ Ag-NPs was evaluated using well diffusion method on Mueller-Hinton Agar (MHA). The inhibition zones were measured in mm ATCC $S$. aureus 25923 was used as a reference for antibacterial assay. Briefly, MHA agar plates were inoculated with 
Table 3: Antibiotic susceptibility of MRSA

\begin{tabular}{|c|c|c|c|c|}
\hline $\begin{array}{l}\text { Antibiotic and } \\
\text { nanoparticles }\end{array}$ & Strength & $\begin{array}{l}\text { Zone size } 15 \text { to } 19 \\
\text { mm (No. of isolates) }\end{array}$ & $\begin{array}{l}\text { Zone size } 20 \text { to } 24 \\
\text { mm (No. of isolates) }\end{array}$ & $\begin{array}{l}\text { Zone size } 25 \text { to } 30 \\
\mathrm{~mm} \text { (No. of isolates) }\end{array}$ \\
\hline Gentamicin & $10 \mu \mathrm{g}$ & 9 & 21 & Nil \\
\hline Clindamycin & $2 \mu \mathrm{g}$ & 9 & 15 & 6 \\
\hline Erythromycin & $15 \mu \mathrm{g}$ & 18 & 12 & Nil \\
\hline Ciprofloxacin & $5 \mu \mathrm{g}$ & 9 & 15 & 6 \\
\hline Linezolid & $30 \mu \mathrm{g}$ & 6 & 21 & 3 \\
\hline
\end{tabular}

MM: Millimeter, MRSA: Methicillin-resistant Staphylococcus aureus

Table 4: Antibacterial activity of silver nanoparticles against MRSA

\begin{tabular}{lll}
\hline Ag-NPs & Strength & Zone size 25-30 mm (No. of isolates) \\
\hline $10 \mathrm{~nm}$ & $12.5 \mu \mathrm{g}$ & 18 \\
$10 \mathrm{~nm}$ & $25 \mu \mathrm{g}$ & 12 \\
\hline
\end{tabular}

mm: Millimeter, MRSA: Methicillin-resistant Staphylococcus aureus

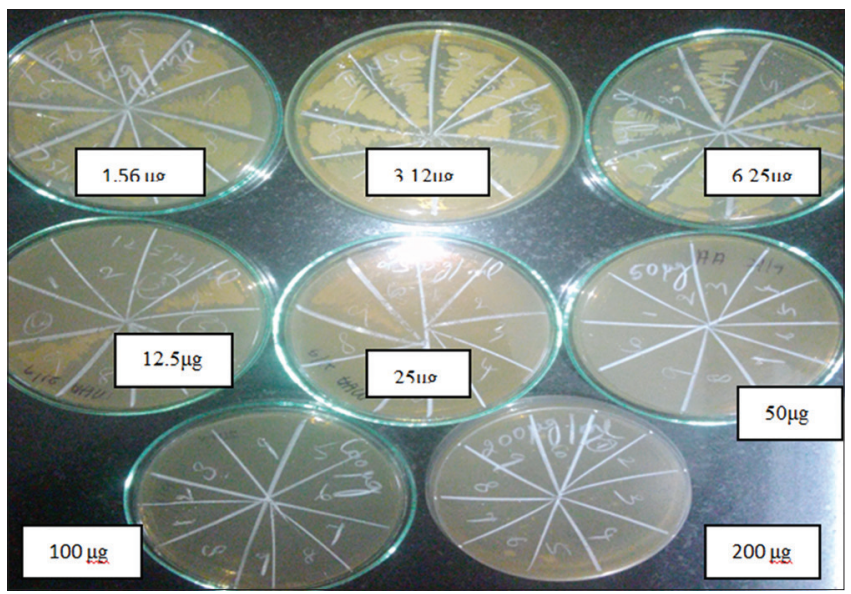

Fig. 5: Minimal bactericidal concentration determination

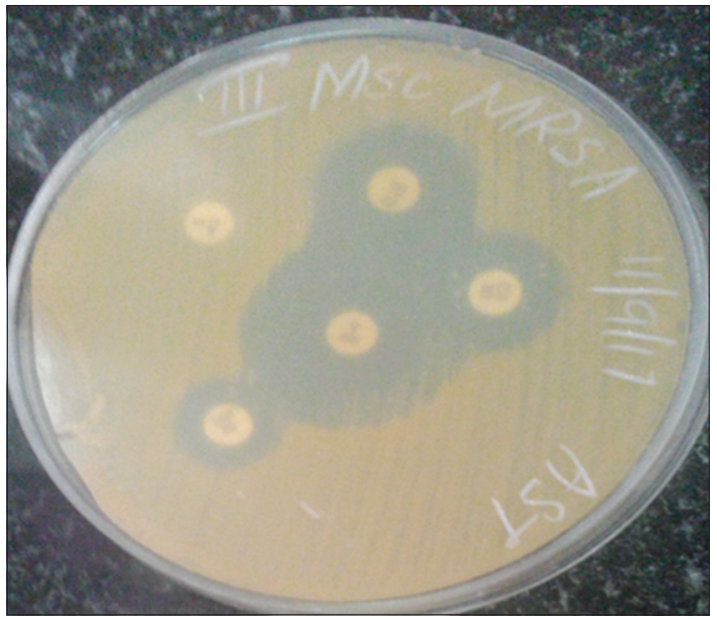

Fig. 6: Disc diffusion assay of antibiotics

bacterial strains under aseptic conditions, and 2 wells $(8 \mathrm{~mm})$ were filled with $12.5 \mu \mathrm{l}$ and $25 \mu \mathrm{l}$ of Ag-NPs and incubated at $37^{\circ} \mathrm{C}$ for $24 \mathrm{~h}$. After the incubation period, the diameter of the growth inhibition zones was measured. 18-24 old single colonies on agar plates were used to prepare the bacterial suspension with the turbidity of 0.5 MacFarland (equal to $1.5^{*} 10^{8} \mathrm{CFU} / \mathrm{ml}$ ).

The zone sizes of antibiotics for isolates are tabulated in Tables 3 and 4 and Fig. 6

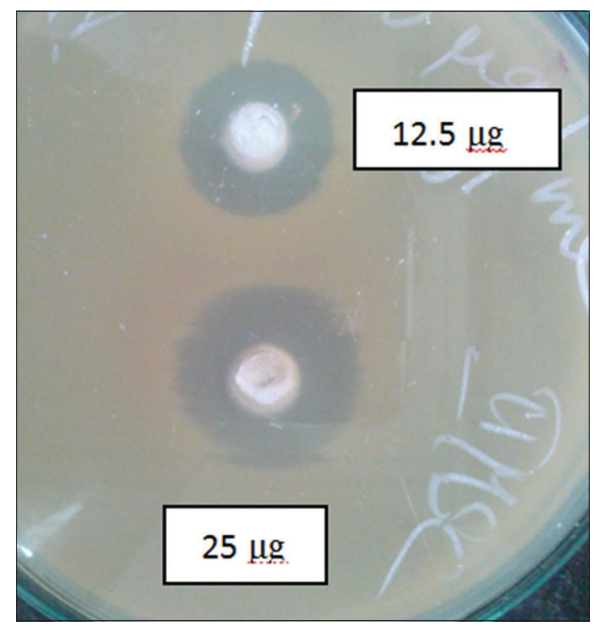

Fig. 7: Well diffusion assay of silver nanoparticles

By comparing the zone sizes of the Ag-NPs and the antibiotics it is evident that the zone size of the Ag-NPs is greater compared to that of the antibiotics tested which is shown in Fig. 7.

\section{CONCLUSION}

There has been an evolution of MRSA into filter strains that combine antibiotic resistance, transmissibility, and virulence. Biofilm formation results in chronic recurrent staphylococcal infections or treatment failure. Ag-NPs are effective bactericidal agents regardless of the drugresistant mechanisms in MRSA. Therefore, Ag-NPs can be recommended as effective broad-spectrum bactericidal agents. Silver nanoparticles have been proven to inhibit biofilm formation in S. aureus. Hence, this multifaceted nanoweapon can be used not only for treatment but also for the prevention of drug-resistant microbes.

\section{CONFLICT OF INTEREST}

None.

\section{REFERENCES}

1. Cosgrove SE, Sakoulas G, Perencevich EN, Schwaber MJ, Karchmer AW, Carmeli Y, et al. Comparison of mortality associated with methicillin-resistant and methicillin-susceptible Staphylococcus aureus bacteremia: A meta-analysis. Clin Infect Dis 2003;36:53-9.

2. Grundmann H, Aires-de-Sousa M, Boyce J, Tiemersma E. Emergence and resurgence of meticillin-resistant Staphylococcus aureus as a public-health threat. Lancet 2006;368:874-85.

3. Wu SW, de Lencastre H, Tomasz A. Recruitment of the mecA gene homologue of Staphylococcus sciuri into a resistance determinant and expression of the resistant phenotype in Staphylococcus aureus. J Bacteriol 2001;183:2417-24

4. Ayliffee GA. The progressive intercontinental spread of methicillinresistant Staphylococcus aureus. Clin Infect Dis 1997;24:S74-9.

5. Johnson AP, Pearson A, Duckworth G. Surveillance and epidemiology of MRSA bacteraemia in the UK. J Antimicrob Chemother 2005;56:455-62.

6. Jones N, Ray B, Ranjit KT, Manna AC. Antibacterial activity of znO nanoparticle suspensions on a broad spectrum of microorganisms. 
FEMS Microbiol Lett 2008;279:71-6.

7. Kwon AS, Park GC, Ryu SY, Lim DH, Lim DY, Choi CH, et al. Higher biofilm formation in multidrug-resistant clinical isolates of Staphylococcus aureus. Int J Antimicrob Agents 2008;32:68-72.

8. Lewis K, Klibanov AM. Surpassing nature: Rational design of sterilesurface materials. Trends Biotechnol 2005;23:343-8.

9. Lewis K. Multidrug tolerance of biofilms and persister cells. Curr Top Microbiol Immunol 2008;322:107-31.

10. Martino PD, Fursy R, Bret L, Sundararaju B, Phillips RS. Indole can act as an extracellular signal to regulate biofilm formation of escherichia coli and other indole-producing bacteria. Can J Microbiol 2003;49:443-9.

11. Patel CN, Wortham BW, Lines JL, Fetherston JD, Perry RD, Oliveira MA, et al. Polyamines are essential for the formation of plague biofilm. J Bacteriol 2006;188:2355-63.

12. McGinnis MW, Parker ZM, Walter NE, Rutkovsky AC, Cartaya-Marin C, Karatan E, et al. Spermidine regulates vibrio cholerae biofilm formation via transport and signaling pathways. FEMS Microbiol Lett 2009;299:166-74

13. Kostakioti M, Hadjifrangiskou M, Hultgren SJ. Bacterial biofilms: Development, dispersal, and therapeutic strategies in the dawn of the postantibiotic era. Cold Spring Harb Perspect Med 2013;3:a010306.

14. Lowy FD. Staphylococcus aureus infections. N Engl J Med 1998;339:520-32.

15. Ammendolia MG, Di Rosa R, Montanaro L, Arciola CR, Baldassarri L. Slime production and expression of the slime-associated antigen by staphylococcal clinical isolates. J Clin Microbiol 1999;37:3235-8.

16. Cramton SE, Gerke C, Schnell NF, Nichols WW, Götz F. The intercellular adhesion (ica) locus is present in Staphylococcus aureus and is required for biofilm formation. Infect Immun 1999;67:5427-33.

17. Arciola CR, Baldassarri L, Montanaro L. Presence of icaA and ica DGenes and slime production in a collection of staphylococcal strains from catheter-associated infections. J Clin Microbiol 2001;39:2151-6.

18. O’Neill E, Pozzi C, Houston P, Smyth D, Humphreys H, Robinson DA, et al. Association between methicillin susceptibility and biofilm regulation in Staphylococcus aureus isolates from device-related infections. J Clin Microbiol 2007;45:1379-88.

19. Merz WG, Hay RJ. Topley and Wilson's Bacteriology. $10^{\text {th }}$ ed. New York: ASM Press; 2005

20. Schulman BM, Redfield C, Peng Z, Dobson CM, Kim PS. Different subdomains are most protected from hydrogen exchange in the molten globule and native states of human $\alpha$-lactalbumin. J Mol Biol 1995;253:651-7.

21. Collee JG, Fraser AG, Marmion BP, Simmons A. Mackie and McCartney. 14 ${ }^{\text {th }}$ ed. New Delhi: Churchill Livingstone; 1996.

22. Thill A, Zeyons O, Spalla O, Chauvat F, Rose J, Auffan M, et al. Cytotoxicity of $\mathrm{ceO} 2$ nanoparticles for Escherichia coli. Physicochemical insight of the cytotoxicity mechanism. Environ Sci Technol 2006;40:6151-6.

23. Sondi I, Salopek-Sondi B. Silver nanoparticles as antimicrobial agent: A case study on E. coli as a model for gram-negative bacteria. J Colloid Interface Sci 2004;275:177-82.

24. Lok CN, Ho CM, Chen R, He QY, Yu WY, Sun H, et al. Silver nanoparticles: Partial oxidation and antibacterial activities. J Biol Inorg Chem 2007; 12:527-34

25. Rangari A, Sharma NK, Ms RG, Thakur R, Singh P. Evaluation and efficacy of in-vitro antibacterial activity of silver nano particles against multidrug resistant bacterial Isolates from skin infections of patients at a tertiary care hospital in western Uttar Pradesh of India. Int J Curr Microbiol Appl Sci 2015;4:764-73.

26. Morones JR, Elechiguerra JL, Camacho A, Holt K, Kouri JB, Ram'irez JT, et al. The bactericidal effect of silver nanoparticles. Nanotechnology 2005;16:2346-53.

27. Kvitek L, Panáček A, Soukupová J, Kolář M, Večeřová R, Prucek R, et al. Effect of surfactants and polymers on stability and antibacterial activity of silver nanoparticles (NPs). J Phys Chem 2008;112:5825-34.
28. Nanda A, Saravanan M. Biosynthesis of silver nanoparticles from Staphylococcus aureus and its antimicrobial activity against MRSA and MRSE. Nanomedicine 2009;5:452-6.

29. Panacek A, Kvítek L, Prucek R, Kolar M, Vecerova R, Pizúrova N, et al. Silver colloid nanoparticles: Synthesis, characterization, and their antibacterial activity. J Phys Chem B 2006;110:16248-53.

30. Silver S. Bacterial silver resistance: Molecular biology and uses and misuses of silver compounds. FEMS Microbiol Rev 2003;27:341-53.

31. Choi O, Deng KK, Kim NJ, Ross L Jr., Surampalli RY, Hu Z, et al. The inhibitory effects of silver nanoparticles, silver ions, and silver chloride colloids on microbial growth. Water Res 2008;42:3066-74.

32. Tamayo LA, Zapata PA, Vejar ND, Azócar MI, Gulppi MA, Zhou X, et al. Release of silver and copper nanoparticles from polyethylene nanocomposites and their penetration into listeria monocytogenes. Mater Sci Eng C Mater Biol Appl 2014;40:24-31.

33. Tian N, Zhou ZY, Sun SG, Ding Y, Wang ZL. Synthesis of tetrahexahedral platinum nanocrystals with high-index facets and high electro-oxidation activity. Science 2007;316:732-5.

34. French GL. Bactericidal agents in the treatment of MRSA infections - The potential role of daptomycin. J Antimicrob Chemother 2006;58:1107-17.

35. Gong $\mathrm{P}, \mathrm{Li} \mathrm{H}, \mathrm{He} \mathrm{X}$, Wang $\mathrm{K}, \mathrm{Hu} \mathrm{J}$, Tan W, et al. Preparation and antibacterial activity of Fe3O4@Ag nanoparticles. Nanotechnology 2007;18:1-17.

36. Christensen GD, Simpson WA, Younger JJ, Baddour LM, Barrett FF, Melton DM, et al. Adherence of cogulase negative staphylococi to plastic tissue cultures: A quantitative model for the adherence of staphylococci to medical devices. J Clin Microbiol 1985;22:996-1006.

37. Stepanovic S, Vuković D, Hola V, Di Bonaventura G, Djukić S, Cirković I, et al.APMIS Quantification of biofilm in microtiter plates: Overview of testing conditions and practical recommendations for assessment of biofilm APMIS 2007;115:891-9.

38. Mathur T, Singhal S, Khan S, Upadhyay DJ, Fatma T, Rattan A, et al. Detection of biofilm formation among the clinical isolates of staphylococci: An evaluation of three different screening methods. Indian J Med Microbiol 2006;24:25-9.

39. Grinholc M, Wegrzyn G, Kurlenda J. Evaluation of biofilm production and prevalence of the icaD gene in methicillin-resistant and methicillinsusceptible Staphylococcus aureus strains isolated from patients with nosocomial infections and carriers. FEMS Immunol Med Microbiol 2007;50:375-9

40. Ansari MA, Khan HM, Khan AA, Malik A, Sultan A, Shahid M, et al. Evaluation of antibacterial activity of silver nanoparticles against MSSA and MSRA on isolates from skin infections. Biol Med 2011;3:141-6.

41. Li WR, Xie XB, Shi QS, Duan SS, Ouyang YS, Chen YB, et al. Antibacterial effect of silver nanoparticles on Staphylococcus aureus. Biometals 2011;24:135-41.

42. Kim JS, Kuk E, Yu KN, Kim JH, Park SJ, Lee HJ, et al. Antimicrobial effects of silver nanoparticles. Nanomedicine 2007;3:95-101.

43. Ahmad MI, Srikanth. Prevalence and antimicrobial susceptibility of methicillin resistant Staphylococcus aureus and coagulase negative staphylococci in tertiary care hospital. Asian J Pharm Clin Res 2013;6 Suppl 3:231-4

44. Mary RN, Banu N. Screening of anti biofilm and anti-quorom sensing potential of vitex trifolia in Psuedomonas aeruginosa. Int $\mathrm{J}$ Pharm Pharm Sci 2005;7:242-5

45. Turkyilmaz S, Kaya O. Determination of some virulence factors in Staphylococcus Spp. isolated from various clinical samples. Turk J Vet Anim Sci 2006;30:127-32

46. Agarwal H, Gayathri M. Biological synthesis of nanoparticles from medicinal plants and its uses in inhibiting biofilm formation. Asian J Pharm Clin Res 2017;10:64-8

47. Sunita P, Palaniswamy M. Size dependent application of biologically synthesized silver nanoparticles against bacterial skin pathogens. Asian J Pharm Clin Res 2017;10:192-5. 